\title{
The Black Markets of North Korea
}

\author{
Qifan Xiang \\ Gill St. Bernard's School, Gladstone, NJ, USA \\ Email: 1907096379@qq.com
}

How to cite this paper: Xiang, Q.F. (2019) The Black Markets of North Korea. Modern Economy, 10, 1759-1768.

https://doi.org/10.4236/me.2019.107113

Received: May 6, 2019

Accepted: July 16, 2019

Published: July 19, 2019

Copyright (c) 2019 by author(s) and Scientific Research Publishing Inc. This work is licensed under the Creative Commons Attribution International License (CC BY 4.0).

http://creativecommons.org/licenses/by/4.0/

\begin{abstract}
The aim of this paper is to provide insight into the foreign and domestic economies of North Korea, particularly concerning illicit black market activities. Regime doctrine of the Democratic People's Republic of Korea has been adamant about the country's sustained self reliance, often making claims of this nature through public broadcasts to its citizens. However, through sources demonstrated in this essay North Korea has been shown to be engaging in black markets across the globe, including high quality currency counterfeiting, arms dealing and drug production and trafficking. North Korea's goal of obtaining nuclear weaponry as a means of deterrent against "imperialist" invasion has lead to numerous sanctions imposed by the United Nations in an attempt to obstruct these ambitions. As a result, North Korea has pursued illicit means of gaining funds for their nuclear program, namely the black market. Within the country itself, there has been a growing lack of trust of its citizens towards the state's Public Distribution System in accommodating for their welfare. A nationwide famine which occurred in the mid to late $90 \mathrm{~s}$ left the country destitute with millions dying of starvation. Following this, catastrophe black markets have emerged throughout the country offering a wide range of products previously unavailable through the state's rationing system. Although North Korea maintains its claim to be a functioning communist state, this paper aims to dispute this through demonstrating the rise of the country's participation in both internal and external commercial black markets. This paper consists of an introduction giving a brief overview of the paper's aims and the divergence of regime rhetoric compared to reality. The following section outlines North Korea's emergence as a sovereign state, the ideologies which define this regime; then to the difficulties the country has faced throughout the 20th century and the measures (sanctioned or otherwise) taken to address them. The final section before the conclusion addresses how North Korea has come to depend on Black Markets as a means of financially supporting itself. This is both in relation to its citizens who depend on black markets for day to day living, as well as the regime which has used international black markets to fund the ambitions of the military state.
\end{abstract}




\section{Keywords}

North Korea, Economy, Consumerism, Famine, Black Markets, Sanctions, Nuclear Weapons, Drug Trafficking, Arms Trade, Currency Counterfeiting

\section{Introduction}

Within the past few years, scrutiny of North Korea's actions on the world stage has intensified as the nation draws closer to achieving its ambition of obtaining ballistic nuclear weaponry. Various UN sanctions placed on North Korea have been implemented with the aim of impeding this ambition.

The goal of this paper is to illuminate the illicit economies of perhaps the world's most secretive nation. Providing insight into the economic functioning of the "hermit nation" gives us an idea of pitfalls communist countries faced throughout the 20th century and how North Korea has managed to sustain itself without collapse. Furthermore, this investigation will shed light on the workings of international black markets and how they support rogue states such as North Korea. The secretive nature of North Korea has made it difficult to collect data to analyse its state of affairs. The state is averse to publicising records and those which are must be viewed with scepticism. For these reasons, it can be difficult to find statistics which back the claims made in this thesis, especially those which shed a negative light on the state. Despite this, mirror accounts from trading partners (import records of these partners reflecting exports from North Korea), data from satellites and North Korean defectors all help to paint a picture of life inside the country.

Since North Korea's emergence as a sovereign state following the second world war, the country's economic system has undergone a transformation from a communist model to practicing free market and black market approaches. Domestically the citizens of North Korea have lost faith in the state's Public Distribution System to provide a means for their survival. This has resulted in new black markets emerging in towns and cities across the country.

At a governmental level, as a means of making income to support its bolstered military and to accommodate a widening trade deficit due to UN sanctions restricting exports, there have been numerous state sponsored illicit activities, particularly drug trafficking and counterfeiting. In more recent times these operations have been outsourced by varying degrees to criminal organisations. The country's political class would never publicly admit this, as one national address of the Korean Central News Agency in 1998 stated:

We must heighten vigilance against the imperialists' moves to induce us to "reform" and "opening to the outside world"... We now have nothing to

"reform" and "open." By "reform" and "opening" The imperialists mean to revive capitalism [1].

However, despite stern rhetoric that the state will never submit to capitalism, 
multiple sources have illustrated how citizens of North Korea have been engaging in illicit local and international markets for private gain. In a militaristic state which is insistent on self reliance, how have its citizens managed to create their own economy which flies in the face of party doctrine? This thesis will examine the causes and nature of North Korean participation within Black Markets, both domestically by its own citizens and internationally by state sponsored programs.

\section{Historical Context}

The origin of North Korea as we know it today can be dated back to August 1945 with the removal of the occupational Japanese forces. Aided by the Soviet Union, communist Korean leaders began to divide the peninsula along the 38th parallel. This ultimately lead to a separation of North and South, officially recognised 3 years later [2].

In the years immediately following the country's separation records have shown that the economy of the northern state was in fact more prosperous than that of its southern adversary. This can be attributed to an abundance of natural resources, at the time being the world's second largest producer of magnesia [3]. Despite the grueling Korean war of 1950, which left both north and south Korea destitute [4] the Democratic People's Republic of Korea (North) still maintained an economic lead over the Republic of Korea (South). Records demonstrate [5] that the DPRK's gross domestic product per capita at purchasing power parity in comparison to the ROK as of 1960 was $\$ 137$ vs $\$ 94$. The relative success of the DPRK's economy can be attributed to the support it received from the Soviet Union and China. These two fellow communist supporters would provide aid, most importantly petroleum at heavily subsidised "friendship" rates [6].

Despite these beneficiaries, North Korean political policies were always going to have a negative impact on its long term economic success. This can be found evident in two primary practices which North Korea has maintained throughout its sovereignty. The first being that the state has continually allocated a majority of their assets towards military spending, known as Songun ideology. Figures have shown that at times approximately $25 \%$ of the GNP has been dedicated to military expenditures [7]. This ideology of military first was well illustrated in a state publication:

“A country's development and the ... importance of the military are linked as one... Once we lay the foundations for a powerful self-sustaining national defence industry, we will be able to rejuvenate all economic fields, to include light industry and agriculture and enhance the quality of the people's lives." Nodong Sinmun, 2003, 3 April [8].

This political approach has lead to other sectors in need of funding being routinely neglected. Not only was it a case of military spending being prioritised but the amount of food rations a solider received was substantially more than that of an average citizen. In the late 1980s rice rations were reduced, named as "patri- 
otic rice" in the form of donations to the military [6].

The second reason for its counter-productive nature can be attributed to juche ideology, which loosely translates as self-reliance. Resulting as a backlash to oppressive Japanese colonisation prior to World War II and the horrendous war with its southern neighbour, North Korea has maintained a fanatical insistence on self-sufficiency and isolationism; albeit with assistance from its aforementioned allies [6]. However with the sudden collapse of the USSR in 1990, North Korea felt the negative effects of its ideologies being compounded. Coupled with the demise of its strongest ally, extreme weather conditions including extensive drought and flooding wreaked havoc on the country's food supply network. This nationwide devastation lead to mass famine between the mid to late 90s, with some estimates citing the death toll as high as 1 million or $5 \%$ of its population [9].

The results of this catastrophe are still being felt today and may have acted as a catalyst for the growing distrust of the North Korean citizen's towards their government and its ability to provide food, resulting in them turning to black markets. A 2016 survey conducted by Beyond Parallel, who interviewed current North Korean citizens, found that $100 \%$ of their sample (36/36) believed that the country's Public Distribution System does not provide what they want for a good life [10]. Although natural causes may have provided the DPRK's politicians with a reasonable explanation for the famine of the 90s, in fact their own agricultural policies played a significant role. A central committee based in Pyongyang issued stringent policy on nationwide farming practices, policies which were often not suitable to local conditions [6]. Perhaps the most damaging policy was deforestation. Entire mountainous ranges were cleared of their trees to make way for crop plantation, often in areas where growth of these crops was practically impossible. In 1997 an aid official stationed in the country observed swathes of hillside collapsed as a result of these ineffective polices [11]. In addition to deforestation, a policy to increase meat production through the rearing of goats caused erosion to the countries already limited grazing land [12]. These two factors, along with a lack of petroleum to fuel farm equipment, which had until recently been supplied by the USSR, laid out prime conditions for the country to be ravaged by natural disaster resulting in famine.

Statistics from the era indicate that the North Korean economy contracted by $25 \%$ during the 90 's. As previously mentioned the North Korean GDP as of 1960 had an advantage over that of South Korea. However by 2006 the per capita income of North Korea was estimated to be a mere one seventeenth of its southern neighbour, at \$1108 [13]. It was not until 4 years later, in 2010, that North Korea had reached external trade levels equivalent to that of 1990 [14].

In addition to and as a result of the juche and songun Ideologies, North Korea's economy is hindered due to extensive sanctions implemented by the United Nations Security Council [15]. The primary reason for these sanctions is because of North Korea's nuclear weapons program, although the first sanctions placed by the United States date back to the 1950s aimed at restricting the coun- 
try's financial transactions. In 1988 North Korea was added to the US's list of state sponsors of international terrorism. Significant sanctions were placed in 2004 after North Korea withdrew from the Nuclear Non-proliferation Treaty signalling the pursuit of their nuclear program, this intent was demonstrated by various nuclear weapon tests between 2006 and 2017 [16].

Each successive leader of North Korea views nuclear weapons as their primary means of survival and a deterrent to foreign invasion. Funds earned through state sponsored black market activities are often put towards the country's nuclear program [17].

The mentality and activities which have lead to North Korea's isolation from mainstream international economic networks have caused it to depend on black markets. The approach of North Korean participation in black markets has undergone changes, particularly after the economic collapse of the 1990s [18]. Before this era the citizens were more dependent on the state's welfare system, however in more recent times the state has been more tolerant of its citizens making their own money then paying a percentage to the regime for the privilege to do so [19]. As an expert on North Korean policy, Andrei Lankov stated,

"Under Kim Jong Un, not a single policy has been implemented which would somehow damage the interests and efficiency of private businesses." [20]

Despite these changes, it is only the women who may participate in the markets of the towns and cities as men must be employed in the state run industries [21].

With international black markets North Korea offers numerous different products. Drug sales \& arms trading provide the majority of this illicit income, although they also produce counterfeit currency. Regarding arms sales, the country is has gone through changes in what they can provide to their prospective customers. In the 80s and 90s North Korea was known for exporting ballistic missiles and small arms. In more recent years their main exports have been artillery and conventional weapons, such as tanks, air-defense systems and rocket-propelled grenades to Africa \& the Middle East.

With the North Korean drug trade the state's policies have also undergone changes throughout the past few decades. During the 1980s it was primarily official party workers who were charged with the dealing of drugs. However now more of the responsibilities have been outsourced to criminal organizations and the North Korean regime plays a less active role in organizing these deals. As Sheena Greitens states,

"In short, from 2006 to 2013, drug activity inside North Korea appears to have shifted away from an industry marked by regime sponsorship to one primarily characterized by quasi-private production and crony capitalism-consistent with broader developments in the North Korean economy in recent years" [22].

\section{The Rise of Black Markets}

For decades after the formation of the North Korean state official policy stated 
all food and products are to be only provided by the state to its citizens. The Public Distribution System was the national operation which, in theory, dispensed everything the country's citizens needed to survive. The PDS was comprised of three networks, some with more autonomy from the state than others [23]. The National Distribution System acted as the main provider for the country, controlling at least $60 \%$ of the country's products. It controlled the quantity and type of product throughout all regions of the country. The Cooperative Distribution Association was a semiautonomous network made up primarily of agricultural producers, although fisheries and other commerce participated. Lastly the Farmers Distribution Commerce played the smallest role with the economy where members were permitted to exchange goods amongst each other if they were of surplus amounts to the state's requirements.

However, outside of the PDS public markets, known as Jangmadang, have been operating for the past few decades, operating illegally until 2002 when they were given official recognition [5]. One account has even stated the possibility that this style of market have been operating in Pyongyang since the 1980s [24]. Evidence has shown that around 5 million citizens or $20 \%$ of the population are "directly or indirectly dependent on the markets." [25] As well as 72\% of citizens receiving almost all their income from markets [26].

The Jangmadang have now filled the void in supply which the PDS originally set out to. As these markets proliferate throughout the country, encouraging the concept of consumerism, blackmarkets have emerged in step with their legal counterparts. Locally the illicit markets are known as "Frog Markets" as their vendors will jump up and run when the authorities come to close them down. Within these markets shoppers are able to purchase rice which is prohibited to be sold in the authorised markets [21]. As one account states rice being sold from bags labeled "Republic of Korea" or "World Food Program" [11]. This particular case suggests the work of corrupt government officials making financial gains on rice intended for public distribution. Corrupt officials can also make money from these black markets by running shake downs in the form of taking bribes in return for allowing the vendors to continue operating [26]. Estimates from a 2018 study have gauged the governmental revenue from taxation of these markets to be equivalent to $\$ 56.8$ million dollars per year. Figures from the same study concluded that the largest of these markets, Sunam market of Chongjin, covering an area of $23,557 \mathrm{~m}^{2}$ provided the government with an estimated $\$ 849,329$ per year [26]. Despite most economic figures based on North Korean economic activity can be unreliable at best, this study has a more scientific basis. It was conducted by dividing the area of each market, observed from satellite imagery, into the approximate size of individual stalls then multiplying this number by the annual fee required in order to operate. Information about the stall size and operating fees were supplied by North Korean defectors who had been interviewed for the study.

As for state sponsored means of earning on the black market, the DPRK has many avenues it pursues. Drug manufacture and trafficking has perhaps been 
the most profitable for North Korea. The earliest reported case of this behaviour dates back to 1976 when numerous members of North Korea's diplomatic corps were detained for smuggling illegal cigarettes, alcohol and hashish into European countries [22]. With successive diplomats being caught for similar offences these kind of operations became harder for North Korea resulting in a shift from distribution to production of drugs, principally Methamphetamine. From the 1990s the substance would be produced in state run factories on North Korean soil then distributed with the aid of Asian crime rings [27]. Japan has been found to be a main market for methamphetamine produced in North Korea. In 1997 almost 1,500 kilograms of the substance were seized by Japanese authorities, accounting for one-third of Japan's supply. The seizure was worth an estimated $\$ 3$ million. Conservative estimates have valued North Korea's annual drug trade to be worth $\$ 500$ million, with more extreme estimates stating \$1 billion [28].

Another way in which North Korea operates within the black market is through weapons trade. The country has a history of engaging in deals with any country, regardless of their political stance or intentions. As with drug trafficking, North Korean embassies have played a vital role in organising these black market transactions. Due to the United Nations sanctions previously mentioned, North Korea has been banned from dealing in arm in an attempt to impede their nuclear program [20]. North Korea's primary exports are in small arms, including Kalashnikovs, rockets and machine guns. Alongside Saudi Arabia and Iran, North Korea is considered to be one of the world's largest exporters in this market, worth an estimated $\$ 6$ billion annually [29]. In the past few years seizures of illicit arms have revealed North Korean methods used to evade customs inspections. For example, in 2016 a North Korean freighter named Jie Shun sailing under Cambodian colours towards Egypt was intercepted by customs agents after receiving a tip-off from Washington. What the agents discovered, hidden under containers of iron ore were more than 30,000 rocket propelled grenades. A report by the United Nations stated this was "the largest seizure of ammunition in the history of sanctions against the Democratic People's Republic of Korea." According to reports from US officials North Korea has maintained trade with numerous countries and organisations including Syria, Hezbollah, Uganda and Congo [30]. The Japanese newspaper, Daily Yomiuri cited in 2001 that North Korean weapon exports generated \$580 million [31].

In addition to drug and arms trade, North Korea has a far reaching network distributing counterfeit currency. According to reports from the US Secret Service North Korea is responsible for creating high quality counterfeit $\$ 100$ dollar bills. Known as "Supernotes", they are almost impossible to distinguish from a genuine specimen. In November 2017 a "Supernote" was identified at South Korea's KEB Hana Bank after being examined by a team of forgery experts. A spokesman for the Bank, Lee Ho-jung stated, 'It seems that whoever printed these supernates has the facilities and high level of technology matching that of a government [32]. Although it cannot be verified that North Korea was responsi- 
ble for the production of "Supernotes" it seems unlikely that a criminal organisation would have the means or expertise to create such a high quality counterfeit. As one US government official Danny Glaser stated,

"The North Koreans have denied that they are engaged in the distribution and manufacture of counterfeits, but the evidence is overwhelming that they are... There's no question of North Korea's involvement." [33]

As with any black market activity it is difficult to determine the quantity of forgeries being produced. From reports of US government officials the estimates vary from between $\$ 15$ to $\$ 250$ million dollars worth of fake notes being produced by North Korea annually [22].

The reason behind North Korea engaging in so many Black Market activities can be due to two main issues. Firstly the sanctions which have been placed on the country due to its pursuit of the nuclear program. Findings have shown that when sanctions are increased the amount of illicit activities North Korea engages in also increases [34]. Secondly North Korea has built up a reserve of foreign currency in order to pay for the trade imbalance with China, which as of 2018 is equivalent to approximately $\$ 100$ million each month [15]. Data from 2017 shows that the North Korean international trade deficit is $\$ 1.69$ billion [35]. If the estimates of revenues generated by illicit trade presented in this essay are of any reliability these proceeds go a long way towards balancing this deficit.

\section{Conclusions}

The economic activities of North Korean, as described by the sources referenced in this essay paint a different picture to that of the Party's official stance. Citizens are trading in open markets for a wide range of products having long ago turned their backs on the state's Public Distribution Systems.

Government policies have shown to be ineffective when dealing with the population on a national scale, the most significant example being the famine of the mid to late 90s. With disasters such as this ever present in the national consciousness, there is no surprise that citizens have sought alternative means for their sustenance when trust in the state's methods are low. Either through public markets, which the state has begrudgingly allowed; or black markets extorted by corrupt officials, the citizens of North Korea have found ways to make their own income. As Everard remarked,

"All together markets are one of the regime's greatest domestic dilemmas-it loathes them and probably fears them, but it cannot close them down." [21]

On an international level North Korea has been engaging in black markets for decades as a way of financing its military and nuclear weapons program. From drug and weapon dealing to money counterfeiting, the state has resorted to any means it can think of to fund its ambitions. Sanctions placed by the UN have been used as a way to restrict the country's financial capabilities, although the 
regime has always had the black market to look to when legal alternatives are unavailable.

\section{Conflicts of Interest}

The author declares no conflicts of interest regarding the publication of this paper.

\section{References}

[1] Eberstadt, N. (1999) The End of North Korea. The AEI Press, Washington DC, 13.

[2] Buzo, A. (2002) The Making of Modern Korea. Rutledge, Berkeley.

[3] Sowinski, L.L. (2000) Uncovering Market Opportunities in Asia. World Trade, November, 34-41.

[4] Kuark, Y.T. (1963) North Korea's Industrial Development during the Post-War Period. The China Quarterly, 14, 51-64. https://doi.org/10.1017/S0305741000021019

[5] Choe, S.T. (2015) The New Markets of North Korea: Jangmadang. American Journal of Management, 15, 62-68.

[6] Seth, M.J. (2011) North Korea's 1990s Famine in Historical Perspective. Education about Asia, 16, 25.

[7] Lee, T. (1990) North Korean Economy. Eul Yu Moon Wha Co., Seoul.

[8] Park, A. and Snyder, S. (2013) North Korea in Transition. Plymouth, Rowman \& Littlefield, 141.

[9] Goodkind, D. and West, L. (2001) The North Korean Famine and Its Demographic Impact. Population and Development Review, 27, 219-238.

https://doi.org/10.1111/j.1728-4457.2001.00219.x

[10] Beyond Parallel (2016) Merger Rations, Banned Markets, and Growing Anger toward Government. https://beyondparallel.csis.org/view-inside-north-korea-meager-rations-banned-ma rkets-and-growing-anger-toward-govt

[11] Natsios, A. (1999) The Politics of Famine in North Korea. Special Report.

[12] Park, H.S. (2002) North Korea: The Politics of Unconventional Wisdom. Lynne Rienner, Boulder.

[13] Amal, M. (2015) Power, Ideology, and Resistance to Reform in North Korea.

[14] Reedier, F. (2015) North Korea's Foreign Trade. https://ipfs.io/ipfs/QmXoypizjW3WknFiJnKLwHCnL72vedxjQkDDP1mXWo6uco/ wiki/Economy_of_North_Korea.html

[15] Kuo, M.A. (2018) North Korea's Currency Crisis: US and Chinese Leverage. The Diplomat.

https://thediplomat.com/2018/04/north-koreas-currency-crisis-us-and-chinese-leve rage

[16] Lee, Y.S. (2017) International Isolation and Regional Inequality: Evidence from Sanctions on North Korea Stanford. Stanford University, Stanford. https://doi.org/10.1016/j.jue.2017.11.002

[17] Albert, E. (2019) What to Know about Sanctions on North Korea. Council on Foreign Relations, New York. https://www.cfr.org/backgrounder/what-know-about-sanctions-north-korea

[18] Bajpai, P. (2018) How the North Korea Economy Works. Investopedia. 
https://www.investopedia.com/articles/investing/013015/how-north-korea-econom y-works.asp

[19] Hastings, J. (2017) How Black Market Entrepenuers Thrive in North Korea. The Sydney Morning Herald.

https://www.smh.com.au/opinion/how-black-market-entrepreneurs-thrive-in-nort h-korea-20170426-gvsjov.html

[20] Pearson, J. (2015) North Korea's Black Market Becoming the New Normal. Reuters. https://www.reuters.com/article/us-northkorea-change-insight/north-koreas-blackmarket-becoming-the-new-normal-idUSKCN0SN00320151029

[21] Everard, J. (2011) The Markets of Pyongyang. Korea Economic Institute, Academic Paper Series, Vol. 6, No. 1.

[22] Greitens, S.C. (2014) ILLICIT North Korea's Evolving Operations to Earn Hard Currency. Committee for Human Rights in North Korea, Washington DC.

[23] Lee, S.Y. (1960) Economic Principles. Cho Sun Ro Dong Dang Publication Inc., 24.

[24] Haggard, S. and Noland, M. (2007) Famine in North Korea: Markets, Aid, and Reform. Colombia Press, New York. https://doi.org/10.2139/ssrn.1284487

[25] Mason, R. (2017) In North Korea, Black Markets Are Saving Lives. Foundation for Economic Education.

https://fee.org/articles/in-north-korea-black-markets-are-saving-lives

[26] Cha, V. and Collins, L. (2018) The Markets: Private Economy and Capitalism in North Korea? Beyond Parallel.

https://beyondparallel.csis.org/markets-private-economy-capitalism-north-korea

[27] Kaplan, D. (1999) The Wiseguy Regime. U.S. News and World Report.

[28] Graham, E. (2007) How North Korea Finances It's International Trade Deficit: An Educated Guess. Korea's Economy, 23, 74-82.

http://www.keia.org/sites/default/files/publications/17.Graham.pdf

[29] Laville, S. (2017) North Korea's Secret Small Arms Exports under Spotlight in Global Survey. The Guardian.

https://www.theguardian.com/world/2017/sep/13/north-korea-is-one-of-worlds-mo st-secretive-small-arms-exporters

[30] Warrick, J. (2017) The Weapons Trade That Keeps Kim Jong-un's North Korea Afloat. Financial Review.

https://www.afr.com/news/politics/world/the-weapons-trade-that-keeps-kim-jongu ns-north-korea-afloat-20171004-gytxfl

[31] Yoshiharu, A. (2003) North Korea Missile Exports Earned 580 Million Dollars in 2001. Daily Yomiuri.

[32] Ryall, J. (2017) Quality of Fake "Supernotes" Found in Seoul Fan Suspicions That North Korea Is Forging \$100 Bills. The Telegraph.

https://www.telegraph.co.uk/news/2017/12/11/quality-fake-supernotes-found-seoul -fan-suspicions-north-korea

[33] Mihm, S. (2006) No Ordinary Counterfeit. The New York Times Magazine, 23 July 2006.

[34] Paddon, B. (2018) North Korea Sanctions Impact Mitigated by Illicit Trade. VOA News.

https://www.voanews.com/a/north-korea-sanctions-mitigated-by-illegal-trade/4280 638.html

[35] Simoes, A. (2018) The Observatory of Economic Complexity. https://atlas.media.mit.edu/en/profile/country/prk 